\title{
Eat, Pray, Buy a House: \\ Utopian Visions of Italy in the New Millennium
}

\section{Cristina Perissinotto}

Summary: This article explores the peculiar combination of literary memoir, utopian dream and material culture that sprung from a number of books written about Italy (living in Italy, buying a home in Italy, moving back to Italy) in the new millennium. The famous Under the Tuscan Sun, published in 1996, constitutes one of the earliest and most famous examples of this new genre. According to the Tuscan Sun book, it is not longer enough to travel somewhere, but the traveler needs to commune with the land by owning a piece of it. While relatively new, this particular sub-genre, defined by a critic "brick and mortar travel memoir," has yielded insightful analyses about travels and the encounters with the other in the $21^{\text {st }}$ Century. Memoirs about living, as foreigners, in contemporary Italy are weaved with the utopian dream of finding something in Italy something real: a real sense of community, real food, real feelings, plus a landscape where human interventions have been gentle and capable of creating real beauty. The article examines a number of memoirs written in recent years about Italy. This analysis is conducted primarily from the point of view of utopian studies, but it also explores issues of authenticity and materiality, thereby offering an analysis of the way Italy is nowadays perceived, imagined and idealized in contemporary travel literature.

Notwithstanding the current economic crisis, more and more buyers aspire to owning a home in the Mediterranean. The idea of owning a piece of property, or at least taking residence for an extended period of time in such regions as Tuscany, or Umbria, or the Veneto, has become increasingly more alluring for a large section of the first world population.

The number of memoirs being produced on the topic of travelling, moving and settling in Italy has increased accordingly over the years; often, but not always, they are written by women. Issues of domesticity, aesteticization of everyday life 
and consumption play an important role therein. (Alù, 2). Such memoirs become important when analyzing questions of agency and autonomy, and the encounters with the Italian Others.

The desire of wealthy homebuyers to own a piece of property in a newer, sunnier place is not just restricted to Italy. A similar phenomenon has been observed in other Mediterranean countries, such as Spain (Minder, 2012) where the government, in order to revive a declining economy, has been encouraging foreign nationals to purchase a home there. This phenomenon is also present in Greece (Heimann, 2012) in France as well as in other Mediterranean countries. ${ }^{1}$

The success of Under the Tuscan Sun (The Movie) may be something that happened to Italy rather than for Italy. It was preceded by the success of Francis Mayes' eponymous book which was shortly thereafter followed by Under the Tuscan Sun the Appointment Book, the Calendar, and a sequel, Bella Tuscany. Under the Tuscan Sun belongs to the brick-and-mortar, hoe-and-spade sub-genre of travel memoirs; Peter Mayle's A Year in Provence is its French, and equally successful counterpart.

Over the years, the number of memoirs about visiting, living, and moving to Italy has greatly increased, to the point that they are becoming a corpus. They span from the enthusiastic, (One Thousand Days in Venice, 2003) to the averse (The Reluctant Tuscan, 2006) to the whimsical (Sweet Honey, Bitter Lemons: Travels in Sicily on a Vespa, 2009). They all have at least two things in common: love for Italy and culture shock.

The act of purchasing a home and settling in Italy usually constitutes the motive for these memoirs, while the encounter with the Italian Other is their subtext. Moving to Italy turns out to be never easy, never completely pleasant, although sometimes rewarding in the end. These books (and cinematic adaptations) constitute a reaction - amused, sentimental, even traumatic - to the authors' encounters with the Others and of their changed selves.

This article analyzes some of the reasons why people might resolve to purchase a piece of property in Italy: their dreams, projections, and hopes. It will also uncover what is so attractive about the Italian way of life, that foreign nationals from many different countries decide to take residence there. It will attempt to describe postmodern travel in Italy from the point of view of desire and utopia and will show the necessity of creating a canon and a genealogy of such travels.

\footnotetext{
${ }^{1}$ See for example: Stone, 2003; Drinkwater, 2001; Taylor, 2012.
} 
This study will explore the different attitudes of the new settlers towards the Italian way of life, with particular attention towards food, bureaucracy and the different conception of time. To do so, this paper will utilize a vast critical apparatus, ranging from Gramsci and hegemony, to travel theory, to post-colonial criticism and utopian studies. However, the main theoretical underpinning of this work is utopian theory, and particularly the notion that all desires and projections upon real estate tend to fulfill a scarcity that the utopian dream of life in Italy fulfills.

In recent years a number of articles and books ${ }^{2}$ have analyzed different aspects of the experience of travelling to Italy, in particular to Tuscany. Silvia Ross (2009) calls this thread of travel writing "settlement narratives," and points out how the travel part is usually not prominent in these memoirs. Giorgia Alù defines them as "villa books" (285) and notices, with Wendy Parkins (2004), that such subcategory of travel writing comprises travelogues that "in both their production and reception they are part of the relentless aestheticisation and 'commodification' of everyday life." (286) Grace Russo Bullaro's insightful essay on Frances Mayes' Under the Tuscan Sun (the book) shows that, beyond the tendency to romanticize, demonize or exoticize the Other, "Mayes' ultimate agenda is... primarily about reconfiguring the concepts of self and home." (7) In her article on Frances Mayes and Gary Paul Nabhan entitled "Tuscan Environments and Italian Identities" Silvia Ross points out some of the stereotypes of Mayes' construction of the Other, and how the eye of an environmental anthropologist such as Nabhan is inevitably much more perceptive about the people and places he encounters in his travels through Tuscany.

In her book about Tuscan spaces, Silvia Ross describes, among other things, the authors' ambivalent, and "ultimately paradoxical" stance vis-à-vis the idea of "going native" in Tuscany: "while on the one hand there is a discernible colonialist stance of superiority towards the 'natives,' the writers themselves seem to desire, at least on a certain level, to 'go native' themselves." (Ross, 2010: 128) A critical view of what all this travelling to places like Tuscany does to the "travelees" is found in the rather personal, and yet insightful essay written by Loredana Polezzi. While analyzing issues of authenticity in Tuscan travel narratives, she also points out that authenticity is not really the issue, neither for the writer nor for the reader. The issue is rather that books such as Under the Tuscan Sun are "dealing with the disputed territory of desire." (311)

\footnotetext{
${ }^{2}$ See Russo Bullaro and Ross, 2007 and 2009.
} 
My analysis proposes to examine this desire, for a different time, place and ultimately, lifestyle, from the point of view of utopian theory. The books that the present study will consider more closely are Frances Mayes' Under the Tuscan Sun (1996) and its movie adaptation from 2004. Tim Parks Italian Neighbours (2001) and Marlena de Blasi's tetralogy — One Thousand Days in Venice (2002), One Thousand Days in Tuscany: A Bittersweet Adventure (2004), The Lady in the Palazzo: An Umbrian Story (2006) and That Summer in Sicily: A Love Story (2008).

Under the Tuscan Sun recounts the story of Frances Mayes' adventure of purchasing a house in the town of Cortona (Tuscany). Her very successful book was followed by a movie with the same title (2004), which played up the landscape and added a romantic touch to the story.

Tim Parks wrote about his experience as a British researcher, who moved with his family to the hills near Verona to work at the university. His humorous take on the new culture and society, where he finds himself immersed, is neither self-conscious nor self-reflective. His hilarious encounters with locals are tainted with the half-anthropological, half-comedic gaze of someone rather oblivious to the respective differences in social status and education. He is well-regarded as someone who can describe Italy from the inside

Marlena De Blasi moves to Venice, where she takes up residence for three years; she then moves to Tuscany for another three years. In A Thousand Days in Venice, her first memoir, she discusses her experience within the Venetian society - one of the most difficult and insular communities in Italy. De Blasi's trilogy recounts her time in Venice, then in Tuscany, and finally the search for a home in the town of Orvieto, Umbria.

In Under the Tuscan Sun the protagonist, Frances Mayes, seems to have a fair amount of disposable income and free time: as a professor of creative writing in California, she may have used a sabbatical to purchase and remodel her new home in Tuscany. The love story added to the movie version is a fictional embellishment. The real Frances Mayes, when she moved to Cortona, was with her husband and faced the problems with the house with him

In fact, the different background of these writers is crucial in discussing some of the features of this new trend of travel writing. Notwithstanding the fact that all these writers hail from different cultural contexts, some features of their descriptions of Italy remain constant. As structuralism reminds us, although the number of stories that can be told is quite large, there is only a small number (about 31) of character functions, and every story derives from the combination 
of different character functions. Not all combinations are possible, and some are mandatory, for example open field battle has to be followed by open field victory or loss, and not, for example, by winning at a card game. (Propp, 116)

Here we have a Heroine (seldom a Hero) who faces a Challenge. She rises up to it and comes out Triumphant, after a series of Trials. The task at hand consists in purchasing a dilapidated home, or alternatively in settling into a new difficult place. The Heroine comes out victorious by bringing back to life a house and turning it into a home. The challenge of house-hunting and renovations becomes a life project, and when the housewarming party is finally celebrated, the Heroine has learned and networked enough from living in the new country and restoring an old home to have become a better, happier person.

The movie version of Under the Tuscan Sun plays up the idyllic landscape and the romance. While in the book Frances Mayes moves to Italy with her husband, in the movie the protagonist, Diane Lane, takes a guided tour of Italy after a painful divorce, finds a dilapidated villa called Bramasole and on a whim she decides to purchase it. In the course of the movie she falls in love with a handsome Italian man (Raoul Bova) whose beauty, slick moves and sweet words add to the idyllic charm of the landscape.

Particularly in the movie version, the lady in distress, after her painful divorce, heals not only because of the trip to Italy, but also by fixing a house, which needs love and kindness as much as the woman does. Her new home becomes a metaphor for her intractable life - if it can be fixed, then the woman's life will be fixed as well.

From a psychological point of view, the protagonist engages in a form of reparation, which has been described in the work of Melanie Klein: "in phantasy we re-create and enjoy the wished-for love and goodness of our parents" (Klein, 312). In essence, reparation consists in acting as a good parent towards someone, or something. Making reparation, Klein writes, is "a fundamental element in love and in all human relationships." (Klein, 313) it is "something more than the making of amends... it is rather a reparative gesture towards the damaged world" (Gerity, 20). In the Restoration genre then, the repairing and caring for the house takes on larger meaning - it becomes a way to make amends to the world in order to repair one's life.

The landscape and the lively natives are a part of the attraction of this genre. Both in the book and in the movie, the coveted object of affection turns out to be the Tuscan life, described as a rural, pastoral dolce vita. It is a dream that 
carries with it important economical and ethnographic consequences. The success of these memoirs - books such as Under the Tuscan Sun (1996) and A Year in Provence (1991) — has fuelled the dream of a sweet Mediterranean life for people who enjoy reading them and have the available time and income to invest in this lifestyle.

This migratory movement has an ancient tradition, as it can be traced back at least to the $18^{\text {th }}$ Century and the Grand Tour, with which - mutatis mutandis - it shows clear correlations. As a phenomenon the Grand Tour begun in the $17^{\text {th }}$ and became popular in the $18^{\text {th }}$ century, and it ended before the Congress of Vienna in 1814 (De Seta, 21). The Grand Tour interested wealthy families in England, France, and Germany who sent their offspring on long journeys through Europe; obligatory stopovers were Italy (Brilli, 1995; Cheney, 1998) and France (Bowers, 1997); in Italy they would typically stop in Florence, Venice, Rome and Naples (Naddeo, 2005)

At its height, the Grand Tour was a widespread upper-class tradition; as Jeremy Black argues, "it allowed the young to sow their wild oats abroad and it kept them out of trouble, including disputes with their families, at home. A certain amount of drinking, gaming and wenching was an acceptable cost of the system." (Black, 84). Sociologically it was, in fact, an expedient way to keep the offspring away from family feuds until they were old enough to manage the family estate. Equally important was the need to give the young a worldly education, and allow them to see the ancient monument of the Mediterranean civilizations. The trip could last from a few months to eight years, and that is why, according to Black (84), it was a prerogative of the young. Middle-aged men, who had a family and an estate to administer, did not have that much time to spare.

It was also a way to teach the children of the ruling classes of Northern Europe about the politics, culture, and art of neighboring countries. Mandatory stops along the Grand Tour were France and Italy, but these young men (more rarely women) also ventured much further afield. One striking example of a Grand Tour undertaken by a philosopher with notable results is Tocqueville's journey to America in 1831. Alexis de Tocqueville's initial purpose was to study the American prison system, but the journey became a one-year voyage that allowed him a profound reflection on the differences between France and the New World. His observations were recorded in Democracy in America (1835), which described, with impressive acumen, the customs and institutions of the American democracy, a society that Tocqueville came to admire. 
This is but one example of the reasons why the cultural value of the Grand Tour cannot be underestimated. The ruling classes' supremacy in the social order was predicated also upon cultural hegemony, which, according to Gramsci, is an important part of the ruling classes' practice of power. He distinguishes between direction, of which cultural hegemony is an aspect, and dominion, which is exercised through force: "The supremacy of a social group manifests itself in two ways - domination and intellectual and moral direction. A social group rules over opposing groups, that it tends to eliminate or subdue by armed force, and it exerts moral direction on allied groups or groups with which it has an affinity." ${ }^{3}$ (Gramsci, 70). Cultural hegemony is essential for the control of other social classes and for showing the direction to allied social classes. In fact, according to Gramsci "cultural hegemony is maintained by the promotion of any culture that accommodates people to their social fate" (Battani, Hall, Neitz, 183).

The Grand Tour represents the practice of cultural hegemony because the upper classes sent off their young men (and sometimes women); however, these were young people who kept close connections with the motherland and were meant to return. The trip might have lasted up to eight years, so the connection to home had to be tangible and continuous. Souvenirs and portraits, memoirs and letters served exactly this purpose, to be in touch with the motherland, thereby asserting one's cultural hegemony in absentia.

Under the Tuscan Sun and other similar memoirs bear many resemblances to the Grand Tour. Firstly, the memoirs describe an extended stay, in modern times it may be a sabbatical or early retirement. Secondly, they display a need to commune with the landscape, attained through the purchase of a house. Thirdly, large resources are invested in this endeavour, although rather than in a long journey, they are invested in an extended stay in a new place. And finally, there is sometimes the production of a memoir. Beautifully crafted, published in millions of copies, it is a testimonial of the journey, as well as a sure way to keep connected to the motherland. Once again, it is a way to assert cultural hegemony in absentia. If the aspiration to live for an extended period of time in a Mediterranean country can be traced back to the Grand Tour, the demographics of those who decide to move to Italy have vastly changed. Among these new travellers, there are a few important names, such as Sting and George Clooney, but also regular, middle-aged

\footnotetext{
3 "La supremazia di un gruppo sociale si manifesta in due modi, come dominio e come direzione intellettuale e morale. Un gruppo sociale è dominante dei gruppi avversari che tende a liquidare o a sottomettere anche con la forza armata, ed è dirigente dei gruppi affini e alleati." (Gramsci, 70)
} 
and middle class people, who aspire to spend a significant part of their lives in Southern Europe.

While the most adventurous Grand Tourists of yore ventured sometimes all the way to Turkey, and felt that they had reached the end of the earth, nowadays the exploration has become marginal. Contemporary memoirs are more interested in self-examination, that is, in describing how their authors react to a new place. They also commit to a closer relationship with the land: it is no longer enough for them to visit a place — given enough funds they aspire to owning a piece of it. As the upper classes of the first world become better connected, they have developed a sense of agency that affords them the dream to not just travel, but to make a home in a new country. They have enough resources to purchase property in Italy, but also, like the young Grand Tourists of the $18^{\text {th }}$ Century, leisure time to plan an extended stay.

Movies and memoirs such as Under the Tuscan Sun have created a plethora of myths and desires directed towards what is now known as Chiantishire; a quick Google search shows how Chiantishire is no longer an ironical designation for the Chianti valley, as it is being populated by English and Americans. Where every rural house has been bought and restored, and the price of property has soared so high that locals can hardly afford to purchase a home, Chiantishire is nowadays the regular new designation for Tuscany — an ancient, beautiful region, characterized by attractive, manicured valleys, rolling hills and winding country roads.

Although the British and Americans have always loved those hills, this so-called second renaissance for Tuscany is a relatively recent phenomenon: "As recently as twenty years ago, if you'd told a Tuscan peasant whose dream was to go to America, that his dilapidated old farmhouse would soon become the dream home of wealthy Americans, the peasant would have considered you just this side of a lunatic," writes Dario Castagno, a well-known wine maker and tour organizer in the region. (Castagno, xvi) The injection of this upper-class, residential tourism has indeed changed the landscape and the way its inhabitants think about it.

Today Chianti should be admired and preserved as a repository of natural and cultural beauty. Strangely, this seems to be occurring, thanks, less to the energies of our natives, than to the enthusiasm of tourists and expatriates. The wealth they have brought to the area has contributed dramatically to a second rinascimento. (Castagno, 39) 
Places such as Tuscany, or Umbria, or certain parts of the Veneto and the Piedmont should now be regarded as contact zones. Mary Luise Pratt's classical definition of contact zones is

social spaces where cultures meet, clash, and grapple with each other, often in contexts of highly asymmetrical relations of domination and subordination — such as colonialism, slavery, or their aftermaths as they are lived out across the globe today." (Pratt, 2).

Moreover, both types of narrative, the memoirs and the counter-narratives written by the natives - such as Castagno's Too Much Tuscan Sun - must be interpreted as "autoethnographic expression."(Pratt, 35) In the words of Mary Louise Pratt, autoethnograpy refers to instances "in which people undertake to describe themselves in ways that engage with representations others have made of them." (Pratt, 35). The idea of self-description in the interaction with foreign subjects describes, for example, what tour guide Dario Castagno undertakes, in his memoir entitled Too Much Tuscan Sun. A wine maker, who also gives guided tours to Americans and British Nationals in the Chianti valley, he grew up in England, therefore he has the advantage of knowing English well and is himself in between cultures. He moved to Tuscany with his family at age 11, and after a few years, using his command of English and knowledge of the area, he started giving guided tours of the Chianti valley.

His autoethnography is laced both with irony and self-irony, as he encounters foreign nationals and interacts with them. During a tour of Siena with a couple of rather athletic Americans, he relates this episode

At the heavy clang of bells sounding from the Mangia tower, I realized that it was now time for lunch. My mouth began watering at the prospect of my friend's Nello's pici al tartufo, which I certainly intended to order, until Mr. Franklin said in a serious, if not grave, tone: "Dario, I am sorry, but in Italy you just don't know how to cook Italian food. You get the best genuine Italian food in America. So if you don't mind we prefer to eat over there." I followed the direction of his finger with growing consternation - till it led my gaze smack into the golden arches of McDonald's. (13) 
This story is obviously hyperbolic, and we need to proceed with a healthy ethics of suspicion (Bernasconi, 1990). However, since auto-ethnography, by definition, expresses the voice and feelings of its author, we also need to take it at face value. Castagno experiences first-hand what it means to be in a contact zone, as well as the sense of in-betweenness that comes with it. In The Location of Culture (1994) Homi Bhabha "privileges the cultural notions of liminality and interstices over those of clear-cut binary oppositions between the Self and the Other." (Maufort, 170).

It is in the emergence of the interstices - the overlap and displacement of domains of difference - that the intersubjective and collective experiences of nationness, community interest, or cultural value are negotiated. (Bhabha, 2)

The cultures coming into contact become both liminal, because the visiting American Tourists are out of their element, but also the tour guide is thrown into an experience of in-betweenness that he does not fail to acknowledge in his writing. By inviting his guests to enjoy a true Tuscan delicacy, such as the famous pici al tartufo (a type of pasta with truffles), Castagno attempts to negotiate the cultural differences by asserting a form of cultural superiority. Such assertion is based on history - the tradition of Italian cuisine - and on the empirical experience of past enjoyment on the part of his own fellow nationals and perhaps, other foreigners that he has guided around.

The caricature of the American couple, claiming that Italians do not know how to make Italian food, expresses a form of discomfort, on the part of the author, towards a form of cultural misunderstanding. While the Italian tour guide extends the courtesy of an "authentic" meal, the American couple seems to refuse it, for reasons that he fails to understand. On the other hand, after hours of walking and sightseeing, the couple was probably experiencing a strong sense of displacement, which invariably results in an urge to look for the familiar in an unfamiliar place. Perhaps this was also accompanied by an urge to domesticate ${ }^{4}$ the journey by eating something that felt soothing and familiar.

The memoirs here analyzed express this liminality in a number of ways. They show the internal struggle between the need to conform to a new place

\footnotetext{
${ }^{4}$ Some travel theorists insist on the idea that the journey needs to be domesticated, in order to understand ourselves while travelling. See Robertson, 1994.
} 
and the need to hold on to a value system that is a part of their identity, all the more important because they are abroad and their identity feels threatened. These memoirs empirically describe the cultural negotiation that is necessary to adapt to a new place. The result of such adaptation is a constant identity redefinition on the part of both groups that come in contact.

Sociologically, it is an interesting conundrum. Bordieu notes how individual agency and social structure interact in different ways, and how this interaction forms a habitus, an "acquired system of generative schemes adjusted to the particular conditions in which it is constituted." (Bordieu, 87) Given this theoretical frame, what happens in the memoirs examined can be one of two things: either the habitus is globalized, and prompts the individual to seek a new space and move to a place where the habitus can still be recognizable and socially accepted, or it prompts the agent to relocate, thereby acquiring different habitus-forming practices, that come from the new environment. In both cases, upon reaching the end of the memoir, the habiti of the individuals have changed, because of their interactions with the new place and with the people who live there. Conversely, as the introduction of new agents becomes numerically significant, the locals are also confronted with an increasingly hybridized place, and their habiti change accordingly.

As for the current narratives, the Other is exoticized on both parts. Tim Parks has a piece where he declares his ambivalent love for the Veneto, the area in Northern Italy where he relocated:

[...] this is a proud and profoundly conservative people, as careful observation of ordering at the bar will confirm. And a tightly knit one too.

How is it that they all instinctively sense, without even glancing at stylish watches, that such and such a time is the moment to switch to their aperitivi? How they chuckle and grin when a German orders a cappuccino rather than an espresso after lunch, pouring that milk on to an already full stomach. And here's a curious detail: espresso is always $\mathrm{OK}$, twenty-four hours a day, even corretto (i.e., with grappa), but cappuccino has a very definite time slot: 8-10.30 a.m. Trivia? No, good training.

When the full complexity of these nuances becomes apparent - because the digestivo, the gingerino, the prosecco all have their right times and contexts too - you will be less surprised by 
the labyrinthine process of, say, switching your driving license to an Italian one or sorting out your position vis-à-vis the health system.

There is an order to all things; follow it, even when it borders on the superstitious and ritualistic. (Parks, 19)

In order to enhance their attractiveness, the fastidiousness and stylishness of the Veneti is hyperbolically rendered. Edward Said would probably comment on the fact that the hyperbole is a way to exoticize the Other:

all the figures of speech associated with the Orient [..] are all declarative and self-evident; the tense they employ is timeless eternal; they convey an impression of repetition and strength; they are always symmetrical to, and yet diametrically inferior to, their European equivalent, which is sometimes specified, sometimes not (Said, 72)

If one replaces "Orient" with Italy, and "Europe" with Anglo-American in the quote above, one can clearly detect the exoticization of Italy in the above narratives. Such technique is present at many levels: individually, the fascination with exotic Italy justifies the agent's choice of relocating, or purchasing a house and living in such an inefficient, and cantankerous locale. Globally, the exoticization of Italy represents a gnoseological approach to relay and reduce the complexity of the society into bite-sized materials that are enticing and informative, but only on the surface. Marlena De Blasi writes an interesting paragraph about going to the beach with other Italian ladies:

... hell's eleventh circle. Women lie in the sun and smoke in front of their cabanas for three hours in the mornings, sleep for two hours at home after lunch, return to the beach to lie in the sun and smoke for three hours in the afternoon, until their husbands join them at six thirty for aperitivi, at the hotel bar. Still at the beach, they shower with a cigarette pinched between their lips; they dress with a cigarette pinched between their lips, and, smoking still, they go off to dinner. She, with a skin like a crinkled russet leaf and weighted by a kilo of gold and jewels, seems more exhausted than he. (De Blasi 2002, 103) 
Of course, not all Italian women smoke, not all Italian women sunbathe with such fierce self-abnegation, and more often that not in Italy going to the beach is a couple activity. The reason why these depictions are such stark, blackand-white vignettes has to do with the necessity to create a recognizable contraposition between the two cultures, so as to understand and make them reciprocally better understandable.

Virtually all the authors complain about the paralyzing Italian bureaucracy, and about the impossibility to cut through the red tape. Marlena De Blasi writes:

I begin to understand that it is not so much that the Italian bureaucracy is, itself, twisted, as it is twisted by those who administer it, who inlay and torture it, with their own set of corruptions, personal as thumbprints. There is fundamentally no Italian bureaucracy, only Italian bureaucrats. (De Blasi, 2004: 146).

The inefficiency of the bureaucracy, which one can only understand, or at least come to accept, if one has grown up with it, receives quite a bit of attention in these memoirs, because it is one of the least comprehensible aspects of life in Italy. The love for the country, for the food and sometimes for the people, is put to the test when travellers have to face bureaucracy. When reassuringly simple things are not available in the new country, then trying to go with the flow and keeping one's sense of humour is an act of love for one's new country:

I write checks (...) Signor Martini, the mediatore, (real estate agent) seems pleased, as though we'd given him a gift. For me it's a confusing but delightful way to conduct business. Handshakes all around (...) we are expecting a parchment deed, lettered in ancient script, but no, the notaio is going on vacation and she'll try to get the paperwork before se leaves "Normale" signor Martini says. I have noticed all along that someone's word is still taken for that. (Mayes, 1996: 22)

On the one hand, Mayes seems to be pleased with the old fashioned, gentleman-like behaviour about money and business transactions. On the other hand, the same old-fashioned way of conducting business is also held to American standards of efficiency, and it miserably fails. 
Finally, the money arrives, the account is open. However, they have no checks. This enormous bank, the seat of dozen branches in the gold center of Italy, has no checks to give us. "Maybe next week" Signora Raguzzi explains. "Right now, nothing”. We sputter. Two days later, she calls: "I have ten checks for you." What is the big deal with checks? I get boxes of them at home. Signora Raguzzi parcels them out to us. (Mayes 1996, 20)

The difficulties in receiving cheques, in the mail or otherwise, has to do with the fact that Italians do not write that many, as they are reserved for special, large purchases. They keep a small stash of cheques at home, and they use them only sparingly, partly because of the fundamental distrust of cheques, which derives from a distrust of money.

The issue of money and trust in Italian culture is obviously complex and has been examined in a number of sociological studies. Trust is understood as "the expectation by one person, group, or firm of ethically justifiable behavior-that is, morally correct decisions and actions based upon ethical principles of analysison the part of the other person, group or firm in a joint endeavour or economic exchange" (Hosmer, 390). Trust is a very efficient way of dealing with people in society, because mistrusting and checking everyone all the time would be very time consuming. (Migheli, 299) The other part of the equation has to do with money. The patron saint of Italy is St. Francis of Assisi, who despised money and possessions, founded a religious movement based on pauperism. It is no wonder that Italians are weary of money, and of people handling money, and prefer to avoid cheques if they can.

Something else that new immigrants coming from the first world do not realize is that power travels differently in Italy than anywhere else. Because of its history of sociological and regional fragmentation, power does not travel from the top down, but it spreads in a polycentric pattern. Salvatore Vassallo writes of an "extreme form of 'consensual politics' and dispersal of power." (693). Although, as Vassallo explains, the way of conducting politics in Italy has greatly changed since the 1990s, the extreme fragmentation of power is still endemic to the Italian system. Italy has also been described as a "a highly bargained pluralist democracy with power dispersed across a wide range of arenas" (Hine, 3).

In theory, this would make for a very inefficient bureaucracy; however, in a system where power is so scattered, constant replacements at the top of the 
pyramid will have fewer repercussions at the bottom of the system. The polycentric power structure of Italy is a factor of stability; when power travels like on a highway with a number of exits, and spreads in a scattered, rhyzomatic way, there is extra stability when there are changes at the top.

This misunderstanding creates a sense of displacement that transpires in all the narratives of the authors analyzed. If it is true that " identity is founded on imaginary trajectories of here and there, I and not-I, and hence on metaphors of movement and place." (Robertson, 2) the identity of these travellers is rooted both on this continuous sense of displacement and on a staunch resistance to it.

I am about to buy a house in a foreign country. A house with the beautiful name of Bramasole. [...] the family wisdom runs against this decision. My mother has said "ridiculous" with her certain and forceful stress on the second syllable, "RiDIculous." [...] I quietly have my doubts." (Mayes, 1996: 6).

The sense of displacement creates adjustment descriptions about the Other, as it is often the case in personal narratives of travel. ${ }^{5}$ Cosmopolitanism is always reaffirmed and identity is rearranged as travellers try to make sense of the people and mores they encounter. This often happens through food and general domesticity - especially in Frances Mayes, who writes lyrically about the food, and in Marlena De Blasi, whose descriptions of food and people contribute to mythologizing and orientalizing the landscape and the people:

Why does one always expect a shepherd to be of a certain age, toothless and swathed in skins, a peaked hat pulled low on his brow? This one is perhaps thirty, with eyes green and liquid set wide in his heart-shaped face. [...] He rides a Harley but leaves it in a shed on the edges of his property so as to not disturb the sheep. (De Blasi, 2006: 9)

Given all this, why go through all this trouble? What is so attractive about the Italian way of life that notwithstanding all the problems, moving to Italy or

\footnotetext{
5 "The sense of fragmentation caused by temporary displacement of the travel experience in a diverse culture found in judgments informants make about Chinese food, is further extended to judgments about the social Other, as less worthy, unclean, distrustful, lack of diversity, etc." (Bardhi, Ostberg, Bentsson, 147).
} 
owning property there has become such a powerful social phenomenon? So much so that many people of different provenances (from Tony Blair to Sting to George Clooney) want and have purchased a home there?

It is no bargain either. Even in this long economic crisis, "a three-bedroom farmhouse still costs more than $£ 823,000$ and you can pay as much as $£ 1$ million for a larger property with vineyards." (Tyzack, 2010) A small fortune, unless one is looking for a project; many of the homes in the area will require extensive repairs and one cannot expect to move in immediately, thereby postponing the fulfillment of the dream for a time that can be indefinite.

From a material culture point of view, one could surmise that some of the attractiveness of the Italian way of life is due to Italy's concentration of art in the territory. According to Censis ${ }^{6}$ Italy has approximately 40,000 villas and palaces, 3,000 historical gardens, 20,000 castles, and 1,500 convents. Eighty percent of Italian cities and towns were founded in Medieval, Roman or preRoman era. The great majority of their towns are ancient, and only $30 \%$ of them were founded after the Renaissance. Italians are nowadays more interested in their own artistic treasures, as only $18,9 \%$ of the population claims indifference between living in a historical home as opposed to a modern one, and preferring location above all. Moreover, $50 \%$ of the adult population has visited something historical at least once, and a good number lives in historical homes. It makes a difference whether newcomers decide to live in a metropolitan area or in a small town; as Ross (2010) points out, many of the memoirs about Italy refer to rural or small town settings.

This backdrop for cross-cultural encounters is responsible for what could be seen as a theoretical paradox in Chiantishire. The polycentrism of power in Italian society makes for enough wilderness to make it interesting. But it is a tame wilderness, which appeals to those seeking a more genuine, slow lifestyle. As Alù points out, it "is an evocation of slow living (la vita lenta) based on honesty, simplicity and conviviality." (Alù, 285) The moniker Chiantishire is no longer a mockery, but a real place in southern Europe, where people from the Northern Europe and North America come to visit and often own a country home. There is no doubt that these foreign influences have changed the landscape and in part the identity of the original inhabitants:

\footnotetext{
${ }^{6}$ Censis, or Centro Studi Investimenti Sociali is a foundation that studies trends and tendencies in Italy. Its famous annual report gives a reliable cross-section of the status of Italy any given year. www.censis.it
} 
Foreigners who fell in love with our lands ... forced us to look at these hills with different eyes (says the Marquis Lapo Mazzei, wine producer and owner of an entire village, Fonterutoli, which seems just out of a time machine) In this land you could have cut poverty with a knife, and people ran away. Now everything has changed."7

The idea of buying a house in Italy and settling down there is a dream that presents recognizable utopian underpinnings. According to Ruth Levitas, a utopian dream is designed to close a "scarcity gap" that is present in a society; for example, a scarcity of food will generate a utopia in which food production and distribution are closely monitored. A society always at war will generate a utopia where there are measures in place to limit conflict with other countries, or to have enough resources to win all the wars.

What kind of a scarcity generated these dream of happiness in the hills of Chianti, in the heart of Venice, in the suburbs of Verona? Judging from the needs and dreams that the memoirs generated, they are a general scarcity of time, which results in aspiring to a vita lenta, and a scarcity of love, which results in a desire for more inclusive and close relationships with the land, if not with the people. Silvia Ross attributes to these authors a "denial of coevalness" (2010: 124), a concept borrowed from anthropologist Johannes Fabian according to which the travellers constantly place the travelee in a time different from the present. (124)

There is another sense in which time plays into these travel narratives, and that is the different perception of the passing of time in different cultures. Our perception and description of time in connection with industrial societies has been explored by Henry Bergson and Gilles Deleuze. Bergson described our sense of time as non-linear, while Deleuze, reading Bergson, reinforced the idea of a complexity and non-linearity of time to "address a number of quite specific problems, such as: how does time actually pass? How can time be regained and redeemed? How is time put out of joint and how does duration become pathological?" (Ansell-Pearson, 168) Alexandre Cioranescu presented a comprehensive argument of linear, circular and spiralling time, in which he observed that the

\footnotetext{
${ }^{7}$ Agli stranieri che si sono innamorati delle nostre terre va riconosciuto un merito: ci hanno obbligato a guardare a queste campagne con altri occhi — afferma il Marchese Lapo Mazzei, super produttore di vino e proprietario di un intero borgo, Fonterutoli, che sembra uscito dalla macchina del tempo. - Era una terra, questa, in cui la povertà si tagliava col coltello. Una terra da cui la gente scappava. Ora è cambiato tutto. (Laurenzi, 2003)
} 
concept of linear time is simply too long for our minds to grasp, and that in fact humans see time in segments. (Cioranescu, 3).

Ilio Adorisio added the concept of chronophagy to his investigation about time in industrial societies. The current meaning of this term was formulated by African theorist Achille Mbembe, who saw chronophagy as a tool, in the process of nation building, used to consume and rewrite the past: "More than on its ability to recall, the power of the state rests on its ability to consume time, that is, to abolish the archive and anesthetise time." (Mbembe, 23). On the other hand, Adorisio uses the concept of chronophagy to understand the way post-industrial societies consume time. Although this is not readily apparent, the rhythm of contemporary societies is based on ancient Benedictine convent time, (Adorisio, quoting Foucault, 266 note 34). In industrial societies, what is sacralised is work, (Adorisio, 274) and the culture of otium is damned, replaced by guilt and anguish in the case of idleness or unemployment (274).

Adorisio agues that, while time in industrial society is circular and repetitive, it is perceived as linear because of our ingrained use of watches, that tell time in equal segments. Watches and clocks are convenient to regulate time, but are most useful "to appropriate the time of others." "Since time and work are related, when we work we exchange our time for commodities. Hence, the chronophagy of industrial society consist in having less and less time.

Although a member of the industrialized world, Italy is still traditional enough that the consumption of time may just be a little less apparent. The authors of the memoirs that we are analyzing, coming to Italy from more industrialized countries, perceive Italians as having a different sense of time. In the movie version of Eat Pray Love, men in the barber shop explain to Julia Roberts how wasting time is called '“dolce far niente' — it means 'the sweetness of doing nothing" (Eat Pray Love, 2010) This concept reflects an earlier model of time consumption, which the authors of the memoirs long to incorporate in their lives: "at home I plan a menu ahead, though I frequently improvise when I shop. Here, I only begin to think when I see what's ripe this week."(Mayes, 1996: 120). They themselves begin to think of time in a more spontaneous, unplanned way, as they realize that the culture of otium may not have completely disappeared.

For Frances Mayes the act of purchasing what is in season is almost revolutionary - a way of renouncing an orderly lifestyle where she knows what she will have for lunch and dinner for the entire week, by giving in to the vagaries of

8 “Macchine per l'appropriazione del tempo altrui." (Adorisio, 268) 
the season. She sets out to the market to purchase purple artichokes but "today, not a one. The fagiolini, slender green beans, are irresistible. Should I have two salads, because the beans also would be good with shallot vinaigrette? Why not?" (Mayes, 2004: 110) The scarcity of time and the idea of a country where things move more slowly and doing nothing is sweet, give rise to the dream of a gentler world in which to retire, relocate, spend some time.

However, with an unplanned life comes chaos, and all the narratives analyzed deal with the dichotomy of chaos versus order, complications versus exactitude

And I can't imagine not remembering how Italians adore complication. A small farrago, some shot agony, this they need every day. Less often, but often enough, it's a real breast-beating for which they yearn. A thing innocent of complication is not worth doing. Posting a letter and choosing a tomato are dramatic opportunities.

(De Blasi, 2002: 156)

However, it is not just that Italy is chaotic, and that one has to purchase things when they are available, as opposed to tomatoes in February and oranges in July; there is also the fact that a different order is in place - a more archaic order of seasons, connected to an agricultural life that is also disappearing.

In these memoirs, however, the perceived complexity of the society is often an expression of displacement. Once the authors become more comfortable with a different order of things, they experience many epiphanies, and they witness the life-changing events that they were looking for in the first place. This is ultimately the reason why they often remark on the kindness of people, a notion that brings to the forefront the second, and perhaps most important, scarcity of modern world

a friend says Italy is getting to be just like everywhere else - homogenized and Americanized. I want to drag her here and stand her in this doorway. The men have the look of their lives - perhaps we all do. Hard work, their faces and bodies affirm. All are lean, not a pound of extra fat anywhere. They look cured by the sun, so deeply tan they probably never go pale in winter. Their country clothes are serviceable, rough — they don't 'dress' they just get dressed. They wear, as well, a natural dignity. Surely some are canny, crusty, cruel but they look totally present, unhidden, and alive. 
Some are missing teeth but they smile widely without embarrassment [...] A retarded boy wanders among them neither catered to nor ignored. He's just there, living his life like the rest of us. (Mayes, 1996: 64)

In the above description we encounter a series of virtues that are attributed to Italian men that stand about this café in Tuscany. Men are described as sincere, wholesome and healthy. Simple but dignified, dressed well but not too well, and lean. And they are kind, not condescending nor oblivious of the retarded boy. Who would not want to live among these people?

There is no doubt that Italians can be very friendly and often very kind - or they can be unfriendly, aggressive and aloof, it depends. But notice the following passage written by Marlena de Blasi about Venice:

The hours spent in the custody of this society linger, crystalline, as they will for all my days. They taught me about food and cooking and patience. I learned about the moon and the sea, about war and hunger and feasting. They sang me their songs and told me their stories and overtime they became my chosen family, and I their chosen child. I feel the rough touches of their [...] hands and their wet, sour [...] kisses; I see the rheumy color of their old eyes that changed as the sea changed. They are Venice's downstairs maid and butlers, the ones content with their portion in this life, descendants of Venetian women who never [...] sipped tea the Florian. These are the older Venetians, the one who rode the lagoons from their island farms to market, day after day, stopping only to fish for supper or to say prayers in some country church, never once having walked in Piazza San Marco. (De Blasi, 121)

What is the scarcity that this, and many other passages reveal? What do they miss in their own country that they notice when they live in Italy? It seems to be a double scarcity of kindness and community. Or, to simplify, a scarcity of love. It is the need to belong to a place where people are kind and unassuming, where one feels accepted and loved. A primordial, almost preverbal need; although these passages may be seen as falling into the category of romantic travel writing - in the sense that they romanticize the land that they visit - every single one of them 
addresses a love crisis that is both epidemic and endemic to their places of origin. The dream of finding love is itself a utopia; these writers seem to suggest that they have found it in the happiness of a small Italian town.

We should not forget, however, that close-knit Mediterranean communities are based on the shame-and-reward system, and very often use gossip as a means of social control. (Peristiany, 1966; Albera, 2006) Tourists and foreigners, not reared in the culture, are more often than not, unaware of how the system works; and therefore not reacting in the same way the system of shame and reward that is inborn to the natives. The way of life that they are unable to find in certain quaint towns in Illinois or Iowa or Ontario can be found here in Tuscany and Umbria and certain sestieri of Venice. We are unsure, in the end, of what kind of fulfillment it might actually give.

\section{University of Ottawa}

\section{Works Cited}

Adorisio, Ilio. "Ucronia in Oiconomia. Considerazioni sulla cronofagia della società industriale." Giuseppa Saccaro del Buffa and Arthur O. Lewis, eds. Utopia e modernità. Teorie e prassi utopiche nell'età moderna e postmoderna. Roma: Gangemi (1989): 237-276.

Albera, Dionigi. "Anthropology of the Mediterranean: Between Crisis and Renewal." History and Anthropology 17.2 (2006): 109-33.

Alù, Giorgia. "Fabricating Home: Performances of Belonging and Domesticity in Contemporary Women's Travel Writing in English about Italy." Studies in Travel Writing 14.3 (2010): 285-302.

Ansell-Pearson, Keith. Philosophy and the Adventure of the Virtual: Bergson and the Time of Life. London; New York: Routledge, 2002.

Bardhi, Fleura, Jacob Ostberg, and Anders Bengtsson. "Negotiating Cultural Boundaries: Food, Travel and Consumer Identities." Consumption, Markets and Culture 13.2 (2010): 133-57.

Battani, Marshall, John R. Hall, Mary Jo Neitz. Sociology and culture. London: Routledge, 2012.

Bernasconi, Robert. "The Ethics of Suspicion.” Research in Phenomenology 20 (1): 3-18 (1990). 
Bhabha, Homi. The Location of Culture. London; New York: Routledge, 1994, 2004.

Black, Jeremy. The British and the Grand Tour. Dover, N.H.; London: Croom Helm, 1985.

Bourdieu, Pierre. Outline of a Theory of Practice. Cambridge; New York: Cambridge University Press, 1977.

Bowers, Terence N. "Reconstituting the National Body in Smollett's Travels through France and Italy." Eighteenth-Century Life 21.1 (1997): 1-25.

Brilli, Attilio. Quando viaggiare era un'arte: il romanzo del Grand Tour, 1995.

Brilli, Attilio. Un paese di romantici briganti: gli italiani nell'immaginario del Grand Tour. Bologna: Il Mulino, 2003.

Castagno, Dario. Too Much Tuscan Sun, xvi. Guilford, Conn.: Globe Pequot Press, 2005.

Chaney, Edward. The Evolution of the Grand Tour: Anglo-Italian Cultural Relations since the Renaissance. Portland, Ore.: Frank Cass, 1998.

Cioranescu, Alexandre. “The Shape of Time.” Diogenes 38.149 (1990): 1-21.

Cullens, Chris. "Gimme Shelter: At Home with the Millennium.” differences: A Journal of Feminist Cultural Studies 11.2 (1999): 204-27.

Da Celano, Tommaso. Vita seconda di S. Francesco, 2, 65. Pax et bonum (www. paxetbonum.net). Last accessed April 2013. Web.

De Blasi, Marlena. A Thousand Days in Venice: An Unexpected Romance. Chapel Hill, N.C.: Algonquin Books, 2002. . A Thousand Days in Tuscany: A Bittersweet Adventure. Chapel Hill, N.C.: Algonquin Books, 2004.

. The Lady in the Palazzo: An Umbrian Love Story. Chapel Hill, N.C.: Algonquin Books of Chapel Hill, 2006.

. That Summer in Sicily: A Love Story. New York: Ballantine Books, 2008.

De Seta, Cesare. L'Italia del Grand Tour da Montaigne a Goethe. Milano: Mondadori, 1992.

de Tocqueville, Alexis, De la démocratie en Amérique (1835, 1840). Chicoutimi: J-M Tremblay, 2002.

Dickinson, Janet E., Les M. Lumsdon, and Derek Robbins. "Slow Travel: Issues for Tourism and Climate Change." Journal of Sustainable Tourism 19.3 (2011): 281-300.

Doran, Phil. The Reluctant Tuscan. New York: Penguin, 2005. 
Drinkwater, Carol. The Olive Farm: A Memoir of Life, Love, and Olive Oil in the South of France. Woodstock [New York]: Overlook Press, 2001.

Eat Pray Love, directed by Ryan Murphy (2010; Culvert City, CA: Columbia Pictures, 2010), DVD.

Evans, Rhiannon. "Searching for Paradise: Landscape, Utopia, and Rome." Arethusa 36.3 (2003): 285-307.

Fabian, Johannes. Time and the Other. How Anthropology Makes Its Object. New York: Columbia University Press: 1983.

Folks, Jeffrey J. 'Mediterranean Travel Writing: From Etruscan Places to Under the Tuscan Sun.' Papers on Language and Literature 40.1 (2004):102-112.

Fort, Mathew. Sweet Honey, Bitter Lemons: Travels in Sicily with a Vespa. Chatham: UK. Random House: 2009.

Gerity, Lani Alaine. Creativity and the Dissociative Patient: Puppets, Narrative, and Art in the Treatment of Survivors of Childhood Trauma. London; Philadelphia: Jessica Kingsley, 1999.

Germann Molz, Jennie. "Global Abode.” Space and Culture 11.4 (2008): 325-42.

Gordon, Walter M. “Thomas More's Utopia: Preface to Reformation.” Renaissance and Reformation / Renaissance Et Réforme 21, no. 3 (1997): 104.

Gramsci, Antonio. "Il Risorgimento," in Quaderni del carcere. (1948), edited by Vincenzo Gerratana. Torino: Einaudi, 2007.

Heimann, Marshall. "Hunting for Holiday Home Bargains in Crisis-Riddled Greece" Die Welt online. 10 of April 2012, last accessed February 2013. Web.

Hine, David. Governing Italy. The Politics of Bargained Pluralism. Oxford: Oxford University Press, 1999.

Hosmer, Larue Tone. "Trust: The Connecting Link Between Organizational Theory and Philosophical Ethics." The Academy of Management Review. Vol. 20, No. 2 (Apr., 1995): 379-403.

Klein, Melanie. Love, Hate, and Reparation. Ed. J. Rivière. New York: Norton, 1964.

Laurenzi, Laura. "Gli eremiti di lusso del Chiantishire" (La Repubblica, 19 August 2003, 27). Last access, July 2013. Web.

LeGoff, Jacques. Le Moyen Âge et l'Argent, Paris: Perrin, 2010.

Levitas, Ruth. The Concept of Utopia. Syracuse: Syracuse University Press, 1990.

Maufort, Marc. “Captured Images.” Performing the First Nations' “Other.” Bárbara Ozieblo, Bárbara Ozieblo Rajkowska, María Dolores Narbona Carrión, Codifying the National Self: Spectators, Actors And the American Dramatic Text. New York: Peter Lang, 2006. 
Mayes, Frances. Bella Tuscany: The Sweet Life in Italy. New York: Random House, 1999.

. Bringing Tuscany Home : Sensuous Style from the Heart of Italy. New York: Broadway Books, 2004.

. In Tuscany. Eds. B. Krist and E. K. Mayes. London: Ebury, 2000. . Under the Tuscan Sun. New York: Random House, 1996.

Mayle, Peter. A Year in Provence. London: Penguin, 2000.

Mbembe, Achille. "The Power of the Archives and Its Limits," Hamilton, C., ed. Refiguring the Archive. Dordrecht: Klower Academic Publishers (2002): 19-26.

Migheli, Matteo. "Assessing Trust through Social Capital? A Possible Experimental Answer." American Journal of Economics and Sociology 71.2 (2012): 298-327.

Mikkonen, Kai. "The "Narrative is Travel” Metaphor: Between Spatial Sequence and Open Consequence." Narrative 15.3 (2007): 286-305.

Minder, Raphael, "Spain Woos Foreigners to Thin Its Inventory of Unsold Homes." New York Times: November 19, 2012. Last accessed February 2013, Article. Web.

Naddeo, Barbara Ann. "Cultural capitals and cosmopolitanism in eighteenthcentury Italy: the historiography and Italy on the Grand Tour" Journal of Modern Italian Studies. Volume 10.2 (June 2005): 183-199.

Parkins, Wendy. 'At Home in Tuscany: Slow Living and the Cosmopolitan Subject', Home Cultures, 1, no. 3 (November 2004): 257-74.

Parks, Tim. Italian Neighbors. New York: Grove Press, 1992, 2003.

Peristiany, John, ed. Honour and Shame: The Values of Mediterranean Society. Chicago: University of Chicago Press, 1966.

Polezzi, Loredana. 'Did someone just travel all over me? Travel writing and the travelee...' Seuils et Traverses: Enjeux de l'écriture du voyage. II. Eds. Jean-Yves Le Disez and Jan Borm. Brest: Centre de Recherche Bretonne et Celtique (2002): 303-12. . Translating Travel. Contemporary Italian Travel Writing in English Translation. London: Ashgate, 2001.

Powers, Alice, ed. Tuscany in Mind: An Anthology. New York: Vintage Books, 2005.

Pratt, Mary Louise. Imperial Eyes. Travel Writing and Transculturation. London; New York: Routledge, 1992. 
Propp, Vladimir Jakovlevič. Morfologia della fiaba; Torino, Einaudi, 1966.

Robertson, George. "As the World Turns," in Travellers' Tales: Narratives of Home and Displacement. Edited by Jon Bird et al. London: Routledge, 1994.

Ross, Silvia. "Home and Away: Tuscan Abodes and Italian Others in Contemporary Travel Writing." Studies in Travel Writing 13.1 (2009): 45-60.

. "The Myth of the Etruscans in Travel Literature in English." Myths of Europe. Eds. Richard Littlejohns and Sara Soncini. Amsterdam and New York: Rodopi (2007): 263-73.

. 'Tuscan Environments and Italian Identities in Gary Paul Nabhan and Frances Mayes.' Arts et Identité Régionale - D'un Sud à l'autre: des rives de la Méditerranée au golfe du Mexique. Eds. Paul Carmignani and Tony Jappy. Cahiers de l'Université de Perpignan. 32 (2001): 171-85.

. Tuscan Spaces: Literary Constructions of Place. Toronto: University of Toronto Press, 2010.

Russo Bullaro, Grace. "Frances Mayes' Bella Tuscany and the Reconfiguration of Self and Home." Essays in Arts and Science 34.1 (2005): 7-19.

Said, Edward. Orientalism. New York; Toronto: Random House; Vintage Books, 1979, 1994, 2003.

Schama, Chloë. "Italian Ways: On and Off the Rails from Milan to Palermo." Smithsonian. 44, 4, 99, July 2013.

Stone, Tom. The Summer of My Greek Taverna: A Memoir. New York: Simon \& Schuster, 2003.

Taylor, Ben and Louise Taylor. Moving to Portugal: How a Young Couple Started a New Life in the Sun - and How You Could Do the Same. Cromer [England]: Blue Sea Books, 2012.

Thouroude, Guillaume. "Towards Generic Autonomy: The Récit De Voyage as Mode, Genre and Form." Studies in Travel Writing 13.4 (2009): 381-90.

Tyzack, Anna. "Affordable property for sale in Tuscany" The Telegraph, 2 Jul. 2010. Last access, January 2013. Web.

Vassallo, Salvatore. "Government Under Berlusconi: The Functioning of the Core Institutions in Italy." West European Politics 30.4 (2007): 692-710.

Weingart, Peter, and Sabine Maasen. "The Order of Meaning: The Career of Chaos as a Metaphor." Configurations 5.3 (1997): 463-520.

Wells, Audrey. Under the Tuscan Sun. Burbank, CA: Touchstone Home Entertainment, 2003, 2004. Film. 
Williams, Caro Trainor, ed. Travel Culture: Essays on what Makes Us Go. Westport, Conn.: Praeger, 1998.

Wilton-Ely, John. "'Classic Grounds:' Britain, Italy, and the Grand Tour." Eighteenth Century Life, 28 (2004): 136-165. 